\title{
Cuerpos en pecado \\ de las ánimas del \\ Purgatorio
}

Bodies in Sin of the Purgatory's Souls

DOI: https://doi.org/10.22380/20274688.1416

\begin{tabular}{c} 
Recibido: 30 de julio del 2020 \\
\hline Aprobado: 3 de marzo del 2021 \\
\hline
\end{tabular}

SLENKA LEANDRA BOTELLO GIL*

Universidad Nacional Abierta y a Distancia sbotellog@gmail.com

\section{R E S U M E N}

Desde una perspectiva multidisciplinar, entre los estudios históricos y del arte, el presente artículo analiza las prácticas devocionales en torno a la figura de las ánimas purgantes y el uso social de sus imágenes durante el siglo XvIII en la Nueva Granada. A partir de la construcción de la categoría de cuerpos en pecado, se estudia el lugar de las ánimas como seres mediadores dentro del cuerpo social de la Iglesia católica en el periodo colonial. El texto vincula el análisis de dos pinturas de ánimas que permitirán explorar la dicotomía cuerpo-alma en el discurso teológico, la estrecha relación entre el mundo de los vivos y el mundo de los muertos que las ánimas purgantes permitieron desarrollar y las relaciones de su corporalidad con las prácticas devocionales.

Palabras clave: ánimas del Purgatorio, cuerpo en pecado, representación, prácticas devocionales

* Investigadora y docente de Historia del Arte del pregrado en Artes Visuales de la Universidad Nacional Abierta y a Distancia (UNAD), Bogotá, Colombia. Maestra en Estudios de Arte de la Universidad Iberoamericana, México, e historiadora de la Universidad Nacional de Colombia, Bogotá, Colombia. Sus investigaciones examinan las representaciones del cuerpo disímil y monstruoso en el arte americano de la modernidad temprana. Desarrolla procesos de investigación-creación desde espacios formativos alrededor del tema de lo monstruoso en América, vinculando análisis históricos y metodologías propias de la creación artística para generar propuestas narrativas multimediales. https://orcid.org/0000-0002-5663-9431. 
From a multidisciplinary perspective between historical and art studies, this article analyzes devotional practices around the figure of souls in Purgatory and the social use of their images during the 18th century in New Granada Viceroyalty. From the construction of the category bodies in sin, this paper studies the place of the souls as mediating beings in the social bo- dy of the Catholic Church for the colonial period. The text links the analysis of two paintings of souls that will allow exploring the body/soul dichotomy in theological discourse, the close relationship between the world of the living and the world of the dead that purging souls allowed to develop, and the relationships of their corporality with devotional practices.

Keywords: souls in Purgatory, body in sin, representation, depiction, devotional practices

\section{Introducción}

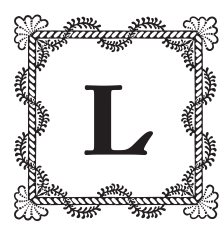

as imágenes de ánimas purgantes fueron una constante durante los siglos XVII y XVIII en distintas regiones de la América española. Su existencia hizo parte de la retórica visual usada por la Iglesia católica para fortalecer la fe, generando fuertes imaginarios sobre la muerte y el más allá, así como una activa y lucrativa dinámica devocional basada en el pago de indulgencias, capellanías y misas a favor de las ánimas de los difuntos.

El presente artículo aborda el desarrollo del concepto de cuerpo en pecado, para el estudio de las representaciones corporales no sacras en la pintura colonial americana, enfocado en las figuras de ánimas purgantes presentes en la pintura neogranadina del siglo Xviri. El carácter teológico de las ánimas purgantes y su expresión corporal serán tratados en este estudio, buscando develar por medio de un acercamiento a las representaciones visuales, las estrechas relaciones, los encuentros y las dinámicas entre los fieles, la iglesia y el imaginario post mortem.

Se desarrollará un análisis de obras neogranadinas acompañado de un análisis contextual comparativo con otros espacios de producción americana como Nueva España, al ser este último un virreinato de gran importancia para comprender las dinámicas evangelizadoras y devocionales que se aplicarían en el resto del continente, y por contar con amplios estudios sobre el tema de las ánimas. En un primer momento, el texto aborda la construcción teórica del 
concepto de cuerpo en pecado, a partir de un repaso de las nociones de cuerpo y representación. Posteriormente, se considera el surgimiento del Purgatorio en la cultura occidental y el desarrollo devocional alrededor de las figuras purgantes en el territorio americano, con base en la lectura de fuentes primarias sobre la buena muerte y el sufragio a las ánimas. Finalmente, se analiza la obra neogranadina Virgen del Rosario y Purgatorio, a la luz del marco teórico de los cuerpos en pecado.

Este trabajo surge de una investigación más amplia, llevada a cabo entre el 2014 y el 2016 como tesis para la maestría en Estudios de Arte de la Universidad Iberoamericana, México. Allí se analizó el significado y la corporalidad de las figuras marginales de demonios, ánimas purgantes y pecadores dentro de la construcción de la imagen religiosa en Nueva Espańa y Nueva Granada en el siglo xvin (Botello). Por cuestiones de extensión y pertinencia, se ha decidido publicar aquí únicamente el estudio actualizado sobre las figuras purgantes.

El estudio propone un enfoque novedoso al análisis de las representaciones de las ánimas purgantes. Para ello, se vincularán los estudios del arte, la mirada histórica sobre el cuerpo y algunos elementos de análisis teológico, buscando develar la compleja red de relaciones entre vivos y muertos que se estableció durante el periodo colonial. Se espera contribuir a la comprensión de los usos sociales de la pintura de ánimas en el territorio neogranadino, y a la discusión sobre el cuerpo como objeto de estudio amplio y el marco teórico para los estudios históricos y del arte.

\section{Cuerpo, representación y pecado}

El cuerpo, experiencia vital compartida por todos los seres humanos, puede ser entendido desde su historicidad dadas las múltiples lecturas, usos y relaciones que las sociedades han hecho de él a lo largo del tiempo y los contextos culturales. En las últimas décadas, el cuerpo se ha convertido en objeto de estudio para diversas disciplinas sociales, más allá del clásico interés médico y científico por su materialidad biológica. En la disciplina histórica dicho interés se observa en la publicación de grandes trabajos compilatorios como Fragmentos para una historia del cuerpo (1992) de Ramona Nadaff, Nadia Tazi y Michael Feher, y los tomos de Historia del cuerpo (2005) editados por Alan Corbin, Georges 
Vigarelo y Jean-Jacques Courtine en los que el cuerpo es texto y subtexto de las investigaciones presentadas ${ }^{\mathrm{I}}$.

Para esta investigación el cuerpo será entendido desde dos perspectivas: como un objeto histórico sobre el que recaen ejercicios constantes de representación, configurando dinámicas sociales de construcción de identidad en torno a sus imágenes, y como estrategia teórico-metodológica de acercamiento a realidades culturales particulares. En ese doble acercamiento se hace necesario encarnar el cuerpo, es decir, encontrarlo en las fuentes y darle sustento a partir del análisis iconológico de las imágenes y del análisis teológico y simbólico que explica su presencia en las obras, configurando así al cuerpo como una estrategia discursiva con usos más allá de la imagen misma.

La representación, por su parte, ha sido una categoría trabajada por la historia cultural y la teoría de la historia. Esta última, basándose en los postulados de Louis Marin, la ha utilizado como categoría analítica para acercarse a producciones discursivas y sus relaciones con las prácticas sociales. Roger Chartier rescató tal influencia señalando la representación como un dispositivo de doble dimensión, una transitiva o transparente, en la cual toda representación representa algo, y una dimensión reflexiva o de opacidad enunciativa, en la que toda representación se presenta representando algo (80), asignando una doble función: "Hacer presente una ausencia, pero también exhibir su propia presencia como imagen y construir con ello a quien la mira como sujeto" (78).

En el análisis de las dinámicas devocionales alrededor de las ánimas purgantes y sus imágenes, la representación se considera un instrumento esencial para comprender modelos de pensamiento y mecanismos de dominación, así como para generar un entendimiento menos opaco de la realidad estudiada. Dicho análisis resulta pertinente puesto que designa "el conjunto de las formas teatralizadas y estilizadas [...] mediante las cuales los individuos, los grupos y los poderes constituyen y proponen una imagen de sí mismos” (Chartier 95).

La antropóloga mexicana Elsa Muñiz sostiene que "las representaciones del cuerpo se convierten en imágenes performativas que proyectan los valores sociales y los sistemas simbólicos en la subjetividad de los individuos mediante los diferentes códigos que las constituyen" (22). Esto supone una dinámica compleja en la que el cuerpo representado responde a esquemas de pensamiento

I Para un análisis historiográfico del cuerpo como objeto de estudio dentro de los estudios históricos y artísticos en Colombia véase Botello, "Encarnar para ver". 
y valores sociales particulares, al tiempo que es forjador de ellos, siendo una relación de ida y vuelta en la que la imagen es constituida y constituye a la vez.

Al estudiar la representación del cuerpo en pinturas de los siglos XVII y XVIII en América, es preciso tener presente que durante el periodo "el cuerpo es lugar y tema de la experiencia religiosa" (Muñiz 95), y como tal, no es una presencia extraña en las imágenes de la época, sino todo lo contrario, una constante de carácter central en las temáticas visuales que permitía generar discursos de poder, transmitir contenidos simbólicos y configurar prácticas sociales y culturales.

El discurso visual barroco en América presenta dos tipos contrapuestos de corporalidades que mantienen una interrelación constante. Por un lado, se observan cuerpos sacros cuya blancura, facciones delicadas, gestos y vestuarios son símbolos de su pureza ontológica. Allí encontramos las representaciones de Jesús, María, Dios Padre, los santos y los ángeles. Cuando las heridas, la sangre o las mutilaciones corporales aparecen, estos elementos son utilizados como símbolos que llevan a la gracia; ni siquiera en los casos de los santos mártires los cuerpos aparecen contaminados por la corrupción de la carne. Por otro lado, hay una presencia importante de cuerpos cuyos gestos, colores, atributos físicos y ubicación espacial determinan su naturaleza corrupta, ligada a la noción de pecado. A ese grupo pertenecen los cuerpos de demonios, pecadores condenados en el Infierno y ánimas del Purgatorio.

En la pintura San Juan Nepomuceno (figura I), anónimo tunjano del siglo XVIII, es posible observar estas dos corporalidades y comprender su interrelación. La imagen presenta a un hombre de piel clara, rostro suave e iluminado por el halo sobre su cabeza, señal de santidad. Viste una capa corta de piel marrón, una medalla devocional — común en las representaciones del siglo XviIIy un roquete blanco que cubre la sotana negra, lo cual indica que ocupa un alto cargo dentro del clero. A sus pies, en una zona de penumbra que contrasta con la luz del santo, se encuentra una figura de rostro y brazos fuertes, característica masculina, en cuyo torso desnudo se observa, prominente, un seno femenino. El resto del cuerpo queda escondido bajo una nube blanca en la que está de pie el personaje central.

Por medio de detalles y alegorías, la imagen cuenta la historia de Juan Nepomuceno, santo del siglo xiv de la región de Bohemia (hoy Chequia), canonizado en I92I, cuya representación, impulsada por los jesuitas, tuvo gran auge en la segunda mitad del siglo XVIII en América (Stépánek 5). Los atributos del santo están claramente definidos: la lengua incorrupta que alza en su mano 


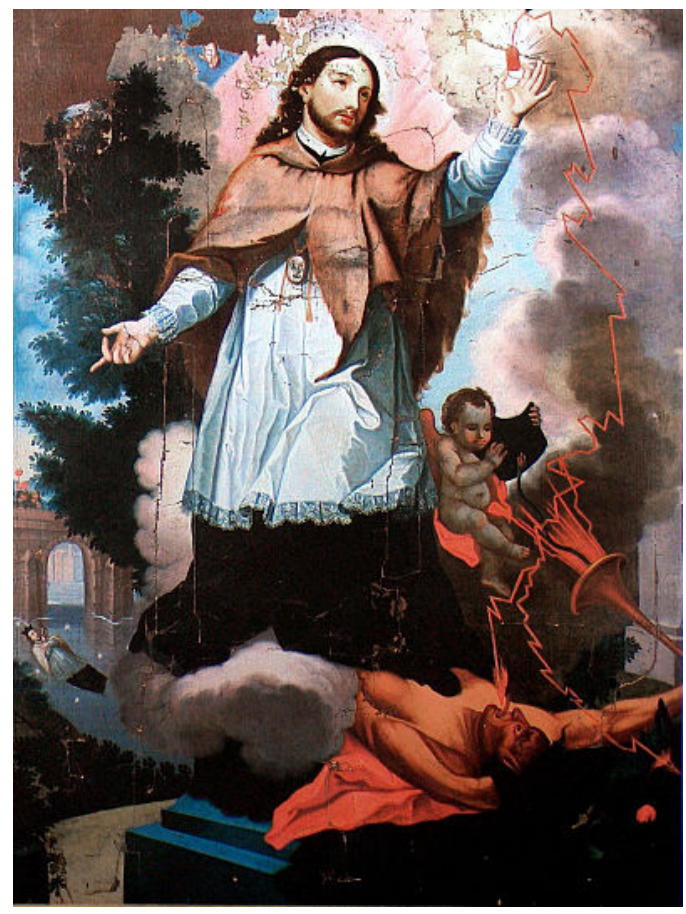

izquierda, símbolo del secreto de confesión guardado hasta su muerte como confesor oficial de la reina Juana de Baviera; el bonete negro, gorro arzobispal que carga el querubín sentado al lado del santo; y la escena de fondo en la que se aprecia el mismo personaje flotando sobre las aguas del río Moldavia, al que Nepomuceno fue lanzado en 1393 por órdenes del rey de Bohemia, Wenceslao IV, por un conflicto político.

La lectura de la obra no estaría completa sin el análisis de la presencia corporal a sus pies. El contraste entre ambos personajes y sus corporalidades es fundamental para descifrar la imagen. Determinado por la piel rojiza y la oscuridad que le rodea, el personaje que yace bajo Nepomuceno es identificado como un demonio. Su figura feminizada se vincula con el pecado original, siendo las mujeres portadoras de esta marca desde el comienzo de la narrativa histórica cristiana. El gesto tranquilo del santo se contrapone al gesto enérgico del demonio de ojos saltones, cejas fruncidas y boca abierta por la que se observa la lengua erguida. Como clave de lectura, el pintor incluyó una centella rojiza que sale de la lengua en alto de Nepomuceno y termina dividida en tres rayos que señalan la lengua del demonio, alegoría de la blasfemia y otros pecados de la palabra; una trompeta con llamas y serpiente, como aquellas del apocalipsis; y un gallo negro que queda oculto entre las sombras de la esquina inferior 
derecha del cuadro, identificado como alegoría del mal. Solo al comprender el antagonismo simbólico entre los cuerpos del santo y el demonio, la historia de san Juan Nepomuceno puede develarse: Nepomuceno, santo mártir, fue una figura de gran relevancia, utilizada por los jesuitas en América como protección contra las habladurías y acusaciones que recaían sobre la Compañía de Jesús.

Los cuerpos de demonios, pecadores y ánimas confluyen en un mismo discurso, se alejan de las "realidades" homogéneas en las que están inmersos, es decir, las nociones de pureza, bien y santidad en las que se enmarca el discurso visual del arte sacro. Pese a ello, para los cuerpos de los pecadores o de las ánimas no puede hablarse de un contraste formal claramente definido con respecto a los cuerpos santos, su diferencia es ontológica, en cuanto que se trata de seres en pecado. Los cuerpos de las ánimas resultan ser un punto medio, pues no son ontológicamente pecadores ni malvadas, como los demonios, ni tampoco tan impuras como los pecadores condenados eternamente al Infierno. Llevan una corrupción menor determinada por los pecados "que levemente se opone[n] a la Ley de Dios, o por la parvidad de la materia, o por falta de plena advertencia" (Diccionario de autoridades, tomo v). En su condición de impureza que debe ser purgada, las ánimas se convierten en símbolo de esperanza para los vivientes, de allí su importancia devocional en América.

\section{Los cuerpos en pecado de las ánimas del Purgatorio}

En el imaginario occidental, marcado por la tradición cristiana, hay una tendencia a comprender la relación alma y cuerpo en términos duales, dándole mayor valor al ente anímico que al físico, por considerar el cuerpo como una cárcel del alma. Sin embargo, no son pocos los postulados teológicos dentro de la misma cristiandad que dan a estos dos elementos del ser un vínculo más profundo, planteando una relación ontológica entre ambos. En las imágenes sobre el Infierno y el Purgatorio es común encontrar la representación corporal de los castigos que las almas sufrirán eternamente, sumado a las descripciones de sermones o de ejercicios espirituales en los que se describe con detalle el olor, el sonido, la temperatura y demás sensaciones físicas experimentadas en el espacio infernal:

Llamas que jamás se confunden [...] tinieblas que jamás se acaban en aquellas cadenas que siempre crujen, en aquella ardiente sed que no tendrá, mientras Dios fuere Dios, una gota de agua de refrigerio [...] 
vista horrorosa de los demonios, en aquel devorarse las carnes a trozo, con sangrienta carnicería, en aquellos infructuosos gemidos, pasmos, rabias y blasfemias. (Castro cit. en Mayer I7I)

Algunos textos doctrinales insistían en que "las almas, aunque espíritus, tenían la capacidad de sentir y que sus sensaciones eran más agudas e intensas que las de los cuerpos" (Wobeser I63). En el siglo Xvi, el alma se definía como un ente espiritual, incorpóreo, e inmortal, que tenía entendimiento voluntad y capacidad para tener sentimientos y memoria y que podía hablar, ver y escuchar y era capaz de recibir alegría y placer y gozo y gloría, lo mismo que sentir tormentos y fatigas y dolores. (Córdoba 309)

Estas referencias señalan el carácter etéreo y eterno del alma y por qué esta podía sufrir en el Infierno o gozar en el Cielo, de forma semejante a las sensaciones corporales. Así, el juego de homólogos alma-cuerpo no resulta ser una contradicción con los planteamientos teológicos, por el contrario, es una explicación de las posibilidades del alma de ser representada.

La preocupación por la relación alma-cuerpo fue una constante en la Edad Media. En el siglo XiII santo Tomás de Aquino fijó una postura en la que alma y cuerpo debían ser concebidos como partes indisociables de la misma unidad, razón por la cual la resurrección de los cuerpos en el Juicio Final era vista como "una implicación del hecho que Dios haya creado la naturaleza humana como una unidad cuerpo/alma” (Bynum 224). De allí que durante los siglos XII a XV la persona se entendiera como una unidad psicosomática:

Theorist in the Middle Age did not see body primarily as the enemy of the soul, the container of the soul, or the servant of the soul; rather they saw the person as a somatic unity, as body and soul together. (Bynum 222)

El Purgatorio, por su parte, se presenta como un lugar donde alma y cuerpo se vinculan en el imaginario. Allí el alma podía ser dotada de un sentido corporal para poder ser representada y que las penas y los sufrimientos de las ánimas fueran mejor comprendidos por los espectadores. Le Goff hace la siguiente apreciación sobre este asunto:

Creer en el Purgatorio supone aclaradas las relaciones entre el alma y el cuerpo. En efecto, la doctrina de la Iglesia sostuvo en seguida que, al morir, el alma inmortal abandonaba el cuerpo y que ya no habrían de volver a encontrarse hasta el fin de los tiempos, con ocasión de la 
resurrección de los cuerpos. Pero la cuestión de la corporeidad o incorporeidad del alma no me parece que haya constituido un problema a propósito del Purgatorio, o de sus esbozos. Se dotó a las almas separadas de una materialidad sui generis y las penas del Purgatorio pudieron de esta forma atormentarlas algo así como corporalmente. (I5)

Esta manera de comprender el cuerpo después de la muerte entra en juego con los postulados de Agustín de Hipona, quien sostuvo que el alma mantiene un vínculo con el cuerpo en el Purgatorio y en el Infierno para poder sentir los tormentos a los que será sometida: “Cómo se puede hablar de la muerte del cuerpo si sigue viviendo por el alma? No puede, en efecto, sentir de otra manera los tormentos corporales que seguirán a la resurrección” (san Agustín 4).

\section{El Purgatorio y el interés por la buena muerte}

El Purgatorio fue apareciendo en el pensamiento cristiano desde el siglo III con las reflexiones de Clemente de Alejandría y de Orígenes, quienes retomaban tradiciones judías y latinas (Borja, "El purgatorio” 155), y continuó gestándose durante la Edad Media por la influencia del Apocalipsis de Pablo (Leal 88). Sin embargo, fue en el siglo xin que se le otorgó un reconocimiento oficial por parte de la Iglesia, haciéndose latente en la mentalidad occidental gracias a su enunciación idiomática y teológica (Le Goff II), derivada de la propuesta de san Agustín de establecer una relación entre Purgatorio y penitencia (Leal 90), y de salvar el alma condenada por medio de un sufragio.

En el siglo Xv ese "tercer lugar" fue denunciado por Lutero al ser un espacio inventado por las leyes canónicas y no por las leyes divinas y haberse convertido en la excusa del papado para recibir el pago de indulgencias a su iglesia, es decir, por haberse convertido en excusa para la corrupción de la institución. Como respuesta, la Iglesia católica lanzó una propuesta política y religiosa durante el siglo Xvi, en el marco del Concilio Ecuménico celebrado en Trento, Italia (I545-1563). Dicha propuesta legitimaba la existencia del Purgatorio, como se lee en el Decreto sobre el Purgatorio de la sesión xxv del Concilio:

Habiendo la Iglesia católica instruida por el Espíritu santo, según la doctrina de la sagrada Escritura y de la antigua tradición de los Padres, enseñado en los sagrados concilios, y últimamente en este general de 
Trento, que hay Purgatorio; y que las almas detenidas en él reciben alivio con los sufragios de los fieles, y en especial con el aceptable sacrificio de la misa; manda el santo Concilio a los Obispos que cuiden con suma diligencia que la sana doctrina de Purgatorio [...] se enseñe y conserve por los fieles cristianos. (327)

La Iglesia establecía la existencia de tres dimensiones distintas pero interconectadas dentro de la institución: la iglesia militante (los vivos); la iglesia purgante, la comunidad de aquellos que debían redimir sus pecados ligeros (las ánimas del purgatorio); y la iglesia triunfante, aquellos que luego de alcanzar la gracia divina disfrutaban de la vida eterna (Borja, "Purgatorios" 90). Dentro del discurso contrarreformista, la existencia de la Iglesia purgante fue de gran importancia puesto que permitía la conexión entre las tres entidades, y con ellas del cuerpo social. Además, legitimaba el sacramento de la eucaristía, que fue fundamental en los procesos de evangelización desarrollados en América y Asia entre los siglos XVI y XVIII.

Al constituirse en un espacio para la purga de las almas de aquellos que cometieron pecados veniales, así como para las almas de personas que tuvieron una muerte súbita y no alcanzaron a tener una última confesión, el dogma del Purgatorio afirmaba la "infinita misericordia de Dios", pues "muchas almas en vez de pasar sus penas en el infierno [...] con una confesión o bien con un arrepentimiento sincero a la hora de la agonía, podrían hacerse merecedoras del purgatorio" (Lugo 29).

Estas almas de los no tan buenos del todo (Le Goff 154 ) entraban a formar parte de una comunidad particular de individuos no solamente juzgados por sus obras, como cualquier otro mortal, sino "una comunidad o sociedad sin estructura o rudimentariamente estructurada [...] individuos que se someten juntos a una autoridad general" y que por su experiencia común pueden ser catalogados como pertenecientes a un grupo definido, el de las benditas ánimas. (Lozada II. Énfasis con cursiva en el original)

Con el surgimiento del Purgatorio, el interés por el momento de la muerte cobró particular importancia. El Purgatorio significó un cambio en las concepciones sobre lo que los fieles debían hacer en vida para preparar su camino tras la muerte, y con ello se desarrolló la idea del bien y mal morir, tema que 
comenzó a gestarse desde el siglo xin en textos piadosos (Soto 22). Así, se configuró una sociedad

regida por el orden religioso, atormentada por la posibilidad de la condenación eterna hacía de los pecadores menesterosos sedientos del perdón, de la recuperación de la gracia por medio de la confesión y la penitencia, deseosos del convencimiento del perdón y de la disminución de las penas que debían purgar después de la muerte corporal. (Lira II42)

En el siglo xv, tras el caos que la peste negra ocasionó en la conciencia colectiva de Europa, la preocupación por la preparación para la muerte se acentuó y comenzaron a publicarse textos del bien morir: los ars moriendi. Estos se produjeron hasta entrado el siglo Xvir y tuvieron una amplia influencia en la mentalidad religiosa americana, hallándose aún estas publicaciones de manera tardía en el siglo XIX (Baz, "Ars" I3). Junto a las imágenes de purgatorios, los ars moriendi cuestionaban a la población sobre sus actos, "[...] las representaciones plásticas dictan a este último ejercicio [el Purgatorio], más impacto entre la población, obligándola a meditar sobre sus actos en vida y sobre su comportamiento a la llegada de la muerte" (Baz, "Por el feliz" IO3). Durante el siglo XviII, este aspecto se fortaleció en los virreinatos americanos, permitió mantener la cohesión social y "orientó al pueblo a seguir los proyectos del Estado" (Soto 7I).

Prepararse para la muerte era de suma importancia, pues se creía que en los momentos previos al deceso, el Demonio aparecería junto al lecho del cristiano para tentarlo de distintas maneras, haciéndolo renegar de la fe, caer en la desesperanza, sufrir de impaciencia, vanagloriarse o ser avaricioso (Soto 34). Si el moribundo llegaba a caer en las tentaciones, perdería la posibilidad de alcanzar la gloria y quedaría condenado para toda la eternidad en el Infierno, entendido esto como una pérdida para la cristiandad.

En el manual Visita de enfermos ejercicio santo de ayudar a bien morir, escrito por el franciscano español Antonio Arbiol y Díez, que circuló en Nueva Granada y en Nueva España a mediados del siglo xviıI, se lee al respecto:

En la Divina Historia de la Mystica Ciudad de Dios, se dice que en la hora de la muerte padecen las almas increíbles y peligrosos trabajos de las asechanzas del demonio, y de la misma naturaleza, y objetos visibles. Aquel punto es, en el que se concluye el proceso de la vida, para que sobre él cayga la última sentencia de muerte, o vida eterna de pena, o Gloria perdurable. (90) 
Luego menciona:

El sagrado concilio Tridentino dize que aunque el Demonio en todo el tiempo de nuestra vida nos hace mucha guerra, pero que se enfurece más contra nosotros en el tiempo de nuestra muerte, viendo que se acaba el tiempo de perdernos. (Arbiol 96)

El énfasis puesto sobre la fuerza de las tentaciones del Demonio en el último momento de la vida servía para legitimar la labor de los "ministros" de apoyar a los moribundos cuidando de sus cuerpos y sus almas.

Así comenzó un diálogo entre vivos y muertos, pues aquel que ayudara al bien morir sería recompensado con sufragios y ayuda prestada por las mismas almas que había encaminado:

Y aunque es ministerio trabajoso, que pide mucho desvelo, consuélense los Ministros del Señor, con la esperanza firme, de que aquellas mismas criaturas, a quien asisten para bien morir, los encomendaran a Dios y les darán las gracias luego que lleguen a la presencia Divina. (Arbiol 98)

\section{Diálogos entre el más allá y el acá}

Duelense las benditas Almas de nuestras miserias, siéntenlas, y ruegan a Dios por nosotros, y con gran confianza, porque saben que están en gracia, y amistad de Dios, y que su Magestad les oye, y que despacha benigno sus peticiones en nuestro favor. (Palafox y Mendoza 4)

Aunque a primera vista la relación entre purgantes y militantes parece sencilla, el desarrollo de las creencias populares y del pensamiento teológico sobre las ánimas constituyó un escenario complejo, de mutua ayuda en diversos planos de la existencia espiritual, que llevó al surgimiento de prácticas y devociones específicas de ese contexto:

La Iglesia es, [y ha sido], una institución que desarrolla diversos mecanismos de cohesión —entre ellos, uno de los más poderosos será el pensamiento de la muerte- y que pide la participación activa de todos sus miembros para lograr la salvación de las almas y la reducción de los tiempos de espera de aquellos que se encuentran en el Purgatorio. (Baz, "Por el feliz tránsito" 206) 
Esa participación activa genera un vínculo basado en la noción medieval de la Iglesia como un cuerpo místico, que funcionó como eje articulador de las sociedades virreinales, entendidas como un cuerpo social en el que cada miembro tenía una función particular. El cuerpo místico estaba encabezado por Cristo y cada una de las tres iglesias estaba reunida en él. Pedro de Ribadeneyra en su texto Flos Sanctorum de la vida de los santos expresa:

se debe presuponer, que toda la Iglesia [...] es un Cuerpo mystico, cuya cabeza es Jesu Christo, en el qual todos los miembros están travados y unidos entre sí por la fe, esperanza y caridad: de tal manera, que assi como en el cuerpo natural, cuando padece un miembro, se compadecen los otros miembros, y se socorren y ayudan. Assi también en este cuerpo mystico espiritual y perfectissimo de la Iglesia lo hacen entre sí los fieles [...] y como las animas de los justos ya difuntos que están en el purgatorio, sean parte y miembros de este cuerpo de la Iglesia por estar unidos con su cabeza. (Borja, "El purgatorio" 330)

La creación de cofradías en España y América es ejemplo del diálogo, sobre todo, la fundación exponencial de cofradías de las Ánimas Benditas del Purgatorio, "llegando a haber una cofradía prácticamente en cada pueblo" (M. Rodríguez IIo). Estas fueron las que más rápidamente se propagaron por los pueblos de españoles y de indios en los reinos americanos. Aun cuando las cofradías se fundaran en honor a un santo o santa específicos, a María o a algún episodio de la vida de Jesús, el objetivo de estas instituciones siempre fue "brindar asistencia espiritual y material a sus miembros" (Martínez et al. 13).

Las cofradías, agrupaciones sociales de origen medieval, han sido definidas como una

comunidad religiosa de individuos seglares católicos, que reglamentada por derecho canónico y autorizada por la jerarquía eclesiástica correspondiente, está destinada a fomentar la devoción y el culto a determinada advocación religiosa [...] cuya acción divina, intercesora, taumatúrgica o heroica propiciarían beneficios tangibles para los devotos en éste y el otro mundo. (Carrera et al. 9)

Junto a las capellanías y las obras pías, las cofradías fueron las instituciones laicas con mayor relevancia en la vida espiritual de los distintos grupos sociales en América entre los siglos XVI y XIX. 
En el Nuevo Reino de Granada, en Santafé, la cofradía de las Benditas Ánimas del Purgatorio, fundada en la Catedral en I6I5, fue la segunda con mayor congregación de fieles, después de la del Santísimo Sacramento (Moreno II9). A mediados del siglo xix aún existía esta hermandad, lo que demuestra la pervivencia de las prácticas religiosas y los imaginarios que las sustentaban. En la Petición que hacen las ánimas del Purgatorio pidiendo el socorro de los sufragios, documento publicado en Bogotá en I838, se puede leer la súplica que hacen las ánimas para su propia salvación, así como la promesa de intercesión que hacen a quienes oren en su nombre:

Nosotras afligidas Ánimas del Purgatorio [...] con toda seguridad recurrimos á vuestra Christina piedad, para recibir alguna caridad, según vuestra grande liberalidad, con que podemos prestamente librarnos de las penas terribles, y de llegár á aquel Reyno dichosísimo, que es la herencia que nos dexó nuestro Redentór por debida correspondencia, que si por vuestra industria, una, ó mas de nosotras entráre en la gloria tan deseada, donde será dotada de inmensas riquezas, y de soberana potencia, aplicará todos sus pensamientos para beneficiaros. Ofrecemos, de socorreros en todas las ocurrencias, de manteneros lejos de las miserias, de defenderos de enemigos, Pero lo que de mayor aprecio y estimación os ofrecemos, y aseguramos es que os impetrarémos de Dios la perseverancia en su gracia y si de ella por vuestra desventura creyeres, serémos vuestras intercesoras delante del mismo Señor, para que hagáis penitencia; os patrocinaremos, en vuestra muerte contra los demonios tentadores, serémos Abogados vuestros, quando fuereis á dar menuda cuenta de vuestra vida pasada á la Divina Justicia [...] (BV Banrep, $O G, \mathrm{I}-2$ )

El sufragio iba acompañado de la obtención en vida de indulgencias individuales para cada creyente, una suerte de "premio espiritual autorizado por el Papa” (Lavrin 52), a partir del pago material o simbólico (oraciones, actos caritativos, ejercicios espirituales), que conllevaba la reducción de la estancia futura en el Purgatorio. En los siglos XviI y XviII las indulgencias formaban parte de una economía espiritual en la cual los fieles llevaban la cuenta de las horas, las semanas y los años que les eran reducidas por cada acción realizada. Pese a ello, los beneficios espirituales que se derivaban y acumulaban con la participación confraternal [no eran solamente un cambalache de beneficios asociado a una numerología simbólica], eran la expresión profunda de 
la fe personal y la promoción de una caridad social que el Estado no ofrecía y cuya administración pertenecía a las instituciones religiosas. (Lavrin 55)

Además de diálogos entre ánimas y vivos, surgieron diálogos que involucraban a santos y santas con el fin de buscar el beneficio de las almas que ya estaban en el Purgatorio y aquellas que aún se encontraban en tierra. Por tal razón, en América gran parte de las pinturas con ánimas en los siglos XVII y XVIII tienen figuras sacras como personajes centrales, entre las que destaca la Virgen María, pues

Las súplicas a la Virgen, la madre de Dios, están consideradas con mayor certeza de cumplimiento que las de cualquier otro santo, y así el Purgatorio, ese tiempo continuo de dolor expiatorio que se extiende entre la muerte y el fin del mundo, es su esfera de especial de influencia. (Warner 4II)

La Virgen del Carmen fue una de las advocaciones marianas reconocidas por interceder a favor de las ánimas. Según relata la historiadora Janeth Rodríguez:

la Virgen prometía liberar del purgatorio el sábado inmediato a su muerte a los carmelitas que fallecieran portando el escapulario bendito. El papa Juan XXII (I3I6) concedió a la orden carmelita las indulgencias de la Bula Sabatina y el papa Benedicto XIII extendió este privilegio a toda la feligresía católica. (198)

La veneración por la Virgen del Carmen y la Virgen del Rosario en territorio neogranadino, así como por la Virgen de la Luz y la Virgen del Carmen en territorio novohispano, estaba vinculada con la función intercesora de la madre de Dios. El despertador espiritual Gritos del Purgatorio y medios para acallarlos, escrito por el franciscano José Boneta y Laplana, da testimonio de la importancia de María para salvaguardar a las ánimas. El escrito comienza con una oración de encomienda a la Virgen del Carmen, en la que se lee:

¡Ah Señora, qué poco desea huir de la acerbidad del purgatorio, y llegar antes al descanso eterno quien no concierta con vos su viaje! ¡Ah cuántos, si se hubieran puesto en esta carroza de vuestra protección, hubieran ya salido de las llamas en que suspiran! (7) 
Para el siglo Xvir se ha registrado una amplia difusión de imágenes con la presencia de figuras purgantes en medio de las llamas, así lo ha demostrado la antropóloga Natalia Lozada en su estudio sobre la incorporación del indígena en la iconografía del Purgatorio, destacando los departamentos de Boyacá y Cundinamarca en la actual Colombia como centros de producción de estas imágenes. Sin embargo, en el siglo XVIII se observa una disminución de la presencia de figuras purgantes, que aparecen las más de las veces en juicios finales y en contadas ocasiones acompañando imágenes marianas, como es el caso de la pintura Virgen del Rosario y Purgatorio (figura 2), del pintor neogranadino Manuel de Sepúlveda, fechada en I78I y albergada hoy en el Museo de Arte Religioso de Popayán.

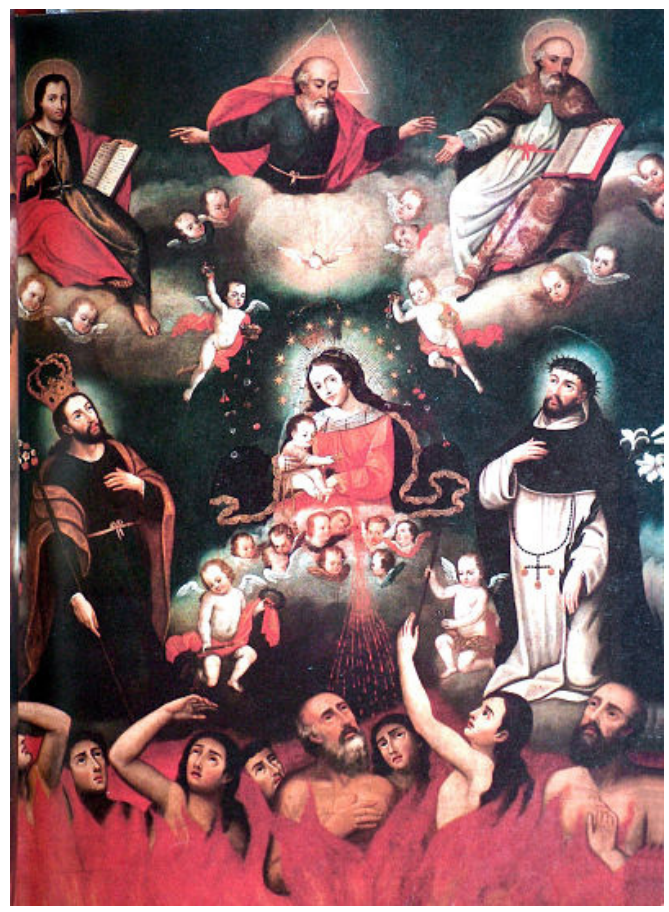

$\leftrightarrow$ FIGURA 2 .

Manuel de Sepúlveda. Virgen del Rosario y Purgatorio. I78I Fuente: ARCA, Jaime Humberto Borja. http://52.183.37.55/artworks/I6460

En la imagen se observan ánimas de ambos sexos abrasadas por las llamas del Purgatorio, recibiendo un baño de sangre purificadora emanada del corazón de la Virgen, que es señalado por el niño Jesús, mientras que María porta un rosario en la mano derecha, identificando su advocación y el vínculo con las 
plegarias por la salvación de las ánimas que debían llevar a cabo los devotos². Junto a ella, del lado derecho, se encuentra Jesús adulto, coronado y con cetro de flores, mientras a la izquierda aparece santo Domingo de Guzmán coronado con espinas, portando en su torso otro rosario, otorgado por la Virgen, según la hagiografía del santo. En la parte superior de la imagen se representa a Dios Padre en el centro, determinando el destino de las almas que son salvadas, acompañado por dos personajes que llevan registro de las ánimas salvadas, en una escena que recuerda la corte celestial del Juicio Final. Entre la Virgen y Dios Padre vuela la paloma del Espíritu Santo, completando la trinidad. Por la composición visual y los personajes es posible identificar cómo el cuerpo de la Iglesia católica queda representado, lo que genera una dinámica en la que participan personajes de tres planos distintos: ánimas (purgantes), figuras sacras (triunfantes) y vivos (militantes), entendidos como los observadores de la obra, integrados por medio de la mirada de la Virgen y las posibles prácticas devocionales suscitadas por la escena.

La corporalidad de las figuras construye un elemento clave en el discurso barroco: el gesto. Como herencia medieval, fue uno de los rasgos esenciales de la oralidad, siendo un "lenguaje corporal que actúa como representación, imagen y símbolo, un lenguaje codificado que comunicaba a los sujetos a través del tiempo" (Schmitt 233). Al observar las ánimas, sus manos y rostros construyen gestos como la súplica, los cuales les otorgan un halo de bondad. La gestualidad de los cuerpos en pecado, la mirada hacia lo alto y los labios entreabiertos, punto medio entre los labios cerrados y serenos de los santos que acompañan a la Virgen en la imagen, y los labios abiertos excesivamente de los condenados que gritan en el Infierno, permite observar el sentimiento de arrepentimiento de las ánimas (Borja, Pintura y cultura 136). Sus expresiones se acercan más a lo que Janeth Rodríguez llama la "gestualidad del cristiano", refiriéndose al gesto templado y mesurado que se aleja del "gesto excesivo de la posesión diabólica, y del desenfreno que el paganismo, a través de ritos, carnavales y teatro, transmitía mediante el cuerpo" (I58).

2 En Colombia tanto la Virgen del Rosario como la Virgen del Carmen dieron lugar a unas de las mayores devociones, que se han extendido hasta nuestros días desde la época colonial. En el caso de la Virgen del Carmen se encuentran referencias como la siguiente: "Según la tradición, si un creyente está a punto de morir y ha portado el escapulario durante su vida, la virgen intercede para que su alma salga del purgatorio el sábado siguiente a la muerte de la persona" (Banco de la República, “Una mirada”). 
Los cuerpos en pecado de las ánimas se presentan de manera pulcra, las llamas cubren púdicamente los torsos. Ni el gesto ni la carne se muestran corruptos, contrariamente a lo que sucede en las imágenes infernales (figura 3), en las cuales el dolor continuo, producto del pecado, acompaña al cuerpo. En Las penas del infierno, la disposición de los cuerpos, la exposición de los senos y las tripas, los ojos desorbitados y los gestos de dolor y angustia se distancian de los cuerpos casi pulcros de las ánimas, cuya relación con el pecado es menor y de cierta manera ya tienen un pie en el cielo; solo ruegan para reducir su tiempo de pena en ese espacio intermedio de purga y consecuente salvación.

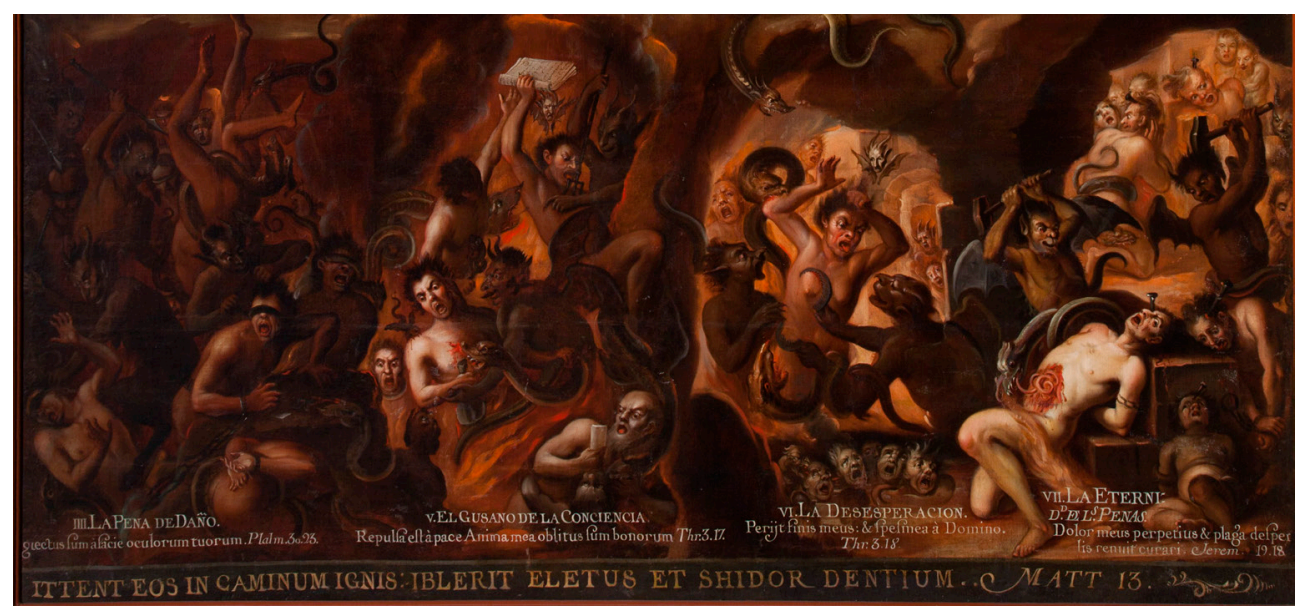

$\rightarrow$ FIGURA 3 .

Autor desconocido. Las penas del infierno (detalle). Siglo xviII Fuente: fotografía de Francisco Kochen

Los gestos de las manos de ánimas y figuras sacras, sus miradas y la construcción espacial en la obra, plantean el trasfondo teológico y moral de la pintura de Sepúlveda. Las ánimas, purgando sus pecados, piden socorro a la Virgen María, a quien dirigen por completo su mirada. La Virgen invita al espectador a hacer parte de esta suplica, recordando la necesidad de la Iglesia militante de orar por las almas de los difuntos para reducir el tiempo de sus penas. A su vez, María rocía a las ánimas con ese baño de sangre purificadora que resulta ser una acción determinada por el hijo de Dios, quien cumple los designios de su padre, pues Dios es el único que puede dictaminar la salvación o no de los mortales y sus almas. La presencia de santo Domingo de Guzmán 
exhibiendo su rosario recuerda a los espectadores la obligación de rezar el rosario diariamente para la salvación de las almas, práctica exigida a todo aquel que entrara en las cofradías de ánimas:

Las Indulgencias del Santísimo Rosario, concedidas por varios pontífices y Prelados, solo están concedidas al Rosario que instituyó la Santísima Virgen y mandó de nuestro Gran Padre, y Patriarca Santo Domingo lo publicara en el mundo [...] Los Cofrades, rezando una parte de Rosario, ganan cien años y cinco quarentenas de Indulgencia. (Barón y Arín 6-I3)

Finalmente, la presencia de la Trinidad y la referencia de la corte celestial al Juicio Final terminan por dejar en claro los dogmas del Purgatorio y el rosario, legitimando su presencia y relación constante e impulsando el desarrollo de las prácticas devocionales que tan largo alcance tuvieron en Nueva Granada: las ánimas y la Virgen del Rosario:

La muerte individual involucra a toda la estructura social e implica un vínculo entre el Purgatorio y la cotidianidad que se ve reflejado en las prácticas de la mortificación, en el buen comportamiento promulgado por la Iglesia en sermones y representaciones iconográficas, donde se representa este espacio de expiación con los santos en actitud de mortificación corporal como figura ejemplarizante frente a las masas. (Lozada 17)

\section{Conclusiones}

Como se ha observado, los cuerpos en pecado de las ánimas purgantes desempeñan un papel fundamental para comprender las complejas dinámicas devocionales desarrolladas en el siglo xviı en Nueva Granada y Nueva España. Al confluir en el discurso de la teología moral, las ánimas representan valores que parecen contraponerse a las nociones de pureza, bien y santidad que caracterizan el discurso y el arte sacro. Sin embargo, estas figuras mediadoras terminan por exaltar dichos valores y develan el diálogo entre la Iglesia mendicante y la Iglesia triunfante.

En la relación entre alma y cuerpo dentro del discurso teológico, en el que muchas veces esta se entiende como una unidad psicosomática (Bynum), aparece también el alma representada como un cuerpo, un cuerpo en pecado, como el de aquellas purgantes. Así, el cuerpo termina por constituirse en una 
explicación y clarificación de las posibilidades del alma de ser representada: presentada y reflejada.

Aunque en esta investigación se decidió abordar la problemática del cuerpo analizando el discurso teológico, no hay que olvidar que el cuerpo es un constructo desde distintos discursos de verdad que se entrecruzan en una misma temporalidad y lo hacen flexible y a veces confuso. Queda abierta la invitación a completar, en futuras investigaciones, esa cartografía del cuerpo vinculando todos aquellos elementos que aquí han quedado por fuera (discurso legal, discurso médico, cosmovisiones alternas).

Al ser elementos importantes para la cohesión social y mecanismos de legitimación de las tres iglesias, los lienzos con presencias de ánimas purgantes se encontraban en iglesias y capillas abiertas a la comunidad en general, y estaban distribuidas no solo en ciudades principales, sino también en poblaciones medianas y pequeñas, lo que las acercaría a un público muy amplio.

Dentro de la imagen, las ánimas concentran la mirada de santos y ángeles que parecen interceder por ellas ante Dios para que les sea concedida la salvación. Así lo deja ver el lienzo Virgen del Rosario y Purgatorio. Fuera de la imagen, estos cuerpos en pecado persuaden por medio de la retórica del gesto al espectador/devoto para que ore por ellas ayudándolas a librarse de la condena eterna, a cambio de prometer interceder ante la divinidad celeste en el momento adecuado para la salvación de aquel creyente y para que se cumplan las distintas peticiones de este en vida.

La presencia de las ánimas acompañando advocaciones marianas cumple una amplia función de legitimación, da sentido a la presencia de la madre de Dios como intercesora entre los vivos y las ánimas, al tiempo que exalta visualmente su figura por medio de la comparación entre su pureza y el cuerpo pecador de las almas. Las ánimas se legitiman como puentes de comunicación entre el espectador y la santa y dejan de ser personajes marginales al contenido de la imagen y dan pie a devociones de largo alcance en el territorio americano.

Quedan aún largos caminos por recorrer en esta historia de los cuerpos en pecado en la pintura americana. Las aproximaciones que aquí hemos presentado han sido una pequeña pero interesante muestra de la riqueza epistemológica que constituye el cuerpo como objeto de estudio y como herramienta metodológica. 


\section{$\infty$ \\ B I B L I O G R A F í A}

\section{FUENTES PRIMARIAS}

\section{A. Archivos}

\section{Biblioteca Nacional de Colombia}

Arbiol, Antonio. Visita de enfermos ejercicio santo de ayudar a bien Morir con las instrucciones más importantes para tan sagrado ministerio que ofrece al bien común Fr. Antonio Arbiol, Religioso de la regular observancia de nuestras seráfica P. S. Francisco de esta Santa provincia de Aragón. Cuarta impresión 1722. Zaragoza: Francisco Morero, 1739.

Ribadeneyra, Pedro de. Flos Sanctorum o libro de las vidas de los santos. Barcelona: Vicente Suria, I688.

\section{Biblioteca FXC, IBERo, México}

Arbiol, Antonio. Visita de enfermos ejercicio santo de ayudar a bien Morir con las instrucciones más importantes para tan sagrado ministerio que ofrece al bien común Fr. Antonio Arbiol, Religioso de la regular observancia de nuestras seráfica P.S. Francisco de esta Santa provincia de Aragón. Impression tercera. 1725 "corregida y añadida por su autor".

Boneta y Laplana, José. Gritos del Purgatorio y medios para acallarlos, libro primero y segundo, dedicados a la Virgen Santissima del Carmen: compuestos por el Doct. Joseph Boneta, Racionero de la Santa Metropolitana Iglesia de Zaragoça y Doctor en Sagrada Theologia. Sexta impresión. León de Francia: Anisson y Posuel, 1709.

\section{Biblioteca Virtual Miguel de Cervantes}

Barón y Arín, Jaime. Tesoro de vivos y limosnero del purgatorio: el rosario de Maria SS. riquissimo de Indulgencias. Valencia: Francisco Burguete, I77I.

Biblioteca Virtual Banco de la República ( $B V$ Banrep)

Obras Generales $(O G)$

Anonimo. "Petición que hacen las ánimas del purgatorio pidiendo el socorro de los sufragios”. Bogotá: José Manuel Galagarza, I838.

\section{B. Impresos}

Palafox y Mendoza, Juan de. Luz a los vivos y escarmiento a los muertos. Madrid: María de Quiñones 166I. 


\section{Imágenes}

Figura I. PESCCA 2515B. Autor desconocido. San Juan Nepomuceno. Siglo XVIII.

Figura 2. ARCA 16460. Manuel de Sepúlveda. Virgen del Rosario y Purgatorio. 1781. http://52.183.37.55/artworks/16460

Figura 3. Francisco Kochen. Autor desconocido. Laspenas del Infierno (detalle). Siglo XVIII. Fotografía cortesía del autor. 2015 .

\section{I F U E N T E S S E C U N DARIA S}

Agustín, Santo Obispo de Hipona. La Ciudad de Dios. Tomo xvi de las Obras completas de San Agustin. Madrid: Biblioteca de Autores Cristianos, 1988.

Baz, Sara Gabriela. "Ars moriendi”. Lexicón de formas discursivas cultivadas por la Compañia de Jesús, editado por Perla Chinchilla. Ciudad de México: Universidad Iberoamericana, 2018 .

---. “Por el feliz tránsito de aquel moribundo’. Tradición y continuidad en las preparaciones para la muerte en el ámbito de Nueva España, siglos XV-XVIII”. Tesis doctoral en Historia. El Colegio de México, 2015.

Botello, Slenka. "Encarnar para ver: la historia del cuerpo y su difusión extracurricular en Colombia”. Recorridos de la historia cultural en Colombia, editado por Sebastián Vargas y Hernando Cepeda. Bogotá: Universidad del Rosario, 2020, pp. 177-200.

Borja Gómez, Jaime Humberto. Pintura y cultura barroca en la Nueva Granada. Los discursos sobre el cuerpo. Bogotá: Alcaldía de Bogotá, Fundación Gilberto Alzate Avendaño, 20 I2.

---. Proyecto ARCA Cultura Visual de las Américas. Bogotá: Universidad de los Andes, 2017202I. http://artecolonialamericano.az.uniandes.edu.co:8080/

--.. "El Purgatorio y la mística en el Nuevo Reino de Granada”. Entre cielos e infiernos: VEncuentro Internacionalsobre Barroco. La Paz: Fundación Visión Cultural, 2018, pp. 155-166.

---. "Purgatorios y juicios finales: las devociones y la mística del corazón en el Nuevo Reino de Granada”. Historia critica, n. ${ }^{\circ} 39$ E, 2009 , pp. 80-I00. DoI: https://doi.org/I0.7440/ histcrit39E.2009.05

---. "Virgen del Carmen". Una mirada a la colección de Arte del Banco de la República. Red Cultural del Banco de la República, 2013. https://www.banrepcultural.org/una-miradaa-la-coleccion/obra.php?i=6 
Bynum, Caroline Walker. Fragmentation and Redemption. Essays on Gender and the Human Body in Medieval religion. Nueva York: Zoom Books, 1992.

Carrera, Eduardo, Clemente Cruz, José Antonio Cruz y Juan Manuel Pérez, coords. Las voces de la fe, las cofradias en México (siglos XVII-XIX). México: Universidad Autónoma Metropolitana / Ciesas, $201 \mathrm{I}$.

Chartier, Roger. "Poderes y límites de la representación. Marin, el discurso y la imagen”. Escribir las prácticas. Foucault, de Certeau, Marin. Buenos Aires: Manantial, 1996.

Concilio de Trento. El Sacrosanto y Ecuménico Concilio de Trento. 1564 . Barcelona: Imprenta de Ramón Martín Indar, I847.

Córdoba, Pedro de. Doctrina cristiana para la instrucción de los indios. Redactada por Fr. Pedro de Córdoba y otros religiosos doctos de la misma orden, editado por Miguel Medina A. Salamanca: San Esteban, 1987.

Corbin, Alan, Jean-Jacques Courtine y Georges Vigarello. Historia del cuerpo. Vols. I, II y III. Madrid: Taurus, 2005.

Lavrin, Asunción. “Cofradías novohispanas: economía material y espiritual”. Martínez, Von Wobeser y Muñoz, pp. 49-64.

Le Goff, Jacques. El nacimiento del Purgatorio. Madrid: Taurus, 1989.

Leal, María del Rosario. “El purgatorio en la plástica neogranadina”. Alarife, Revista de Arquitectura, n. ${ }^{\circ}$ 8, 2009 , pp. 88-95.

Lira, Andrés. "Dimensión jurídica de la conciencia. Pecadores y pecados en tres confesionarios de la Nueva España, I545-1732”. Historia mexicana. México: El Colegio de México, 2006 , pp. II39-II78.

Lozada Mendieta, Natalia. "La incorporación del indígena en el Purgatorio cristiano. Estudio de los lienzos de ánimas de la Nueva Granada de los siglos Xv i y XVII”. Tesis de pregrado en Antropología, Universidad de los Andes, Bogotá, 20 I2.

Lugo Olín, María Concepción. Relatos de ultratumba: Antología de ejemplos sobre el Purgatorio. Ciudad de México: Instituto Nacional de Antropología e Historia (INAH), 2007.

Marin, Louis. De la représentation. Paris: Seuil, 1993.

Martínez, María del Pilar, Gisela Von Wobeser y Juan Guillermo Muñoz Correa. Cofradias, capellanias, y obras pias en la América colonial. México: Universidad Nacional Autónoma de México (UNAM), 1998.

Mayer, Alicia. "El cielo, el infierno y el purgatorio en los sermones novohispanos”. Muerte y vida en el más allá. España y América, siglos XVI-VIII, editado por Gisela von Wobeser y Enriqueta Vila Villar. Ciudad de México: Universidad Nacional Autónoma de México (UNAM); Instituto de Investigaciones Históricas, 2009, pp. 165-180. 
Moreno, Diana. "Un paso a la salvación del alma. Cofradías en Santafé y su estructura social. 1606-1707”. Tesis de pregrado en Historia, Pontificia Universidad Javeriana, Bogotá, 2014.

Muñiz, Elsa. Registros corporales: La historia cultural del cuerpo humano. Ciudad de México: Universidad Autónoma Metropolitana (UAM) Azcapotzalco, 2008.

Nadaff, Ramona, Nadia Tazi y Michel Feher. Fragmentos para una historia del cuerpo bumano. Madrid: Taurus, 1992.

Ojeda, Almerindo. Project for the Engraved Sources of Spanish Colonial Art (PESSCA). 20052021. https://www.colonialart.org.

Real Academia de la Lengua Española. Diccionario de autoridades. Tomo v. Madrid: Real Academia de la Lengua Española, 1738. https://webfrl.rae.es/DA.html.

Rodríguez Álvarez, María de los Ángeles. Usos y costumbresfunerarias en la Nueva España. Morelia: El Colegio de Michoacán A. C., 200 I.

Rodríguez Nóbrega, Janeth. Arte y mistica en Venezuela. Las visiones celestiales y el éxtasis en la pintura de la provincia de Caracas. Caracas: Universidad de Caracas, 2008.

---. "El Purgatorio en la pintura barroca venezolana: iconografía y discurso”. Escritos en Arte, Estética y Cultura. III Etapa, n. ${ }^{\circ}$ 21-22, 2005, pp. 189-208.

Schmitt, Jean-Claude. La raison des gestes dans l'Occident médiéval. París: Editions Gallimard, I990.

Soto Cortés, Alberto. Reina y soberana. Una historia de la muerte en el México del siglo XVIII. Ciudad de México: Universidad Nacional Autónoma de México (UnAm), Coordinación de Estudios de Posgrado, 2010.

Stépánek, Pavel. “San Juan Nepomuceno en el arte español y novohispano”. Cuadernos de Arte e Iconografia, vol. 3, n. 6 , 1990, pp. II-54.

Warner, Marina. Tú sola entre las mujeres. El mito y el culto a la Virgen Maria. Madrid: Taurus, I991.

Wobeser, Gisela von. Cielo, infierno y purgatorio durante el virreinato de la Nueva España. Ciudad de México: Universidad Nacional Autónoma de México (UnAM) / Instituto de Investigaciones Históricas / Estampa Artes Gráficas / Editorial de Otro Tipo, 2015. 